\title{
A narrative review of skeletal muscle atrophy in critically ill children: pathogenesis and chronic sequelae
}

\author{
Chengsi Ong $^{1}$, Jan Hau Lee ${ }^{2,3}$, Melvin K. S. Leow ${ }^{3,4,5,6}$, Zudin A. Puthucheary ${ }^{7,8}$ \\ ${ }^{1}$ Nutrition and Dietetics, KK Women's and Children's Hospital, Singapore, Singapore; ${ }^{2}$ Children's Intensive Care Unit, KK Women's Children's \\ Hospital, Singapore, Singapore; ${ }^{3}$ Duke-NUS Medical School, Singapore, Singapore; ${ }^{4}$ Clinical Nutrition Research Center, Agency for Science, \\ Technology and Research, Singapore, Singapore; ${ }^{5}$ Department of Endocrinology, Tan Tock Seng Hospital, Singapore, Singapore; ${ }^{6}$ Lee Kong Chian \\ School of Medicine, Nanyang Technological University, Singapore, Singapore; ${ }^{7}$ William Harvey Research Institute, Barts and The London School of \\ Medicine and Dentistry, Queen Mary University of London, London, UK; ${ }^{8}$ Adult Critical Care Unit, Royal London Hospital, London, UK \\ Contributions: (I) Conception and design: All authors; (II) Administrative support: None; (III) Provision of study materials or patients: None; (IV) \\ Collection and assembly of data: All authors; (V) Data analysis and interpretation: All authors; (VI) Manuscript writing: All authors; (VII) Final \\ approval of manuscript: All authors. \\ Correspondence to: Chengsi Ong, PhD. 100 Bukit Timah Road, KK Women's and Children's Hospital, Singapore 229899, Singapore. Email: ong.chengsi@ \\ kkh.com.sg.
}

\begin{abstract}
Muscle wasting is now recognized as a growing, debilitating problem in critically ill adults, resulting in long-term deficits in function and an impaired quality of life. Ultrasonography has demonstrated decreases in skeletal muscle size during pediatric critical illness, although variations exist. However, muscle protein turnover patterns during pediatric critical illness are unclear. Understanding muscle protein turnover during critical illness is important in guiding interventions to reduce muscle wasting. The aim of this review was to explore the possible protein synthesis and breakdown patterns in pediatric critical illness. Muscle protein turnover studies in critically ill children are lacking, with the exception of those with burn injuries. Children with burn injuries demonstrate an elevation in both muscle protein breakdown (MPB) and synthesis during critical illness. Extrapolations from animal models and whole-body protein turnover studies in children suggest that children may be more dependent on anabolic factors (e.g., nutrition and growth factors), and may experience greater muscle degradation in response to insults than adults. Yet, children, particularly the younger ones, are more responsive to anabolic agents, suggesting modifiable muscle wasting during critical illness. There is a lack of evidence for muscle wasting in critically ill children and its correlation with outcomes, possibly due to current available methods to study muscle protein turnover in children-most of which are invasive or tedious. In summary, children may experience muscle wasting during critical illness, which may be more reversible by the appropriate anabolic agents than adults. Age appears an important determinant of skeletal muscle turnover. Less invasive methods to study muscle protein turnover and associations with long-term outcome would strengthen the evidence for muscle wasting in critically ill children.
\end{abstract}

Keywords: Muscle protein synthesis (MPS); muscle protein breakdown (MPB); critically ill children; muscle turnover

Submitted Sep 17, 2020. Accepted for publication Dec 18, 2020.

doi: $10.21037 /$ tp-20-298

View this article at: http://dx.doi.org/10.21037/tp-20-298

^ ORCID: 0000-0002-5093-2848.

(C) Translational Pediatrics. All rights reserved. 


\section{Introduction}

Concerns of reduced function and physical impairment in critically ill children following pediatric intensive care unit (PICU) stay have increased in the past few years $(1,2)$. This has prompted the study of interventions, such as early mobilization, in reducing long-term impairments $(3,4)$. In critically ill adults, similar observations of functional impairment have been reported, attributable to acute muscle wasting that occurs during intensive care unit (ICU) stay $(5,6)$. Muscle wasting in critically ill adults is increasingly recognized as a debilitating problem both within and outside the ICU. Significant short term consequences include difficulty in weaning off mechanical ventilation and increased risk of mortality (7). In some patients the effects of muscle wasting can persistent beyond hospital stay, resulting in functional impairment and the inability to carry out activities of daily living or return to work (5).

Critically ill adults experience elevated muscle protein breakdown (MPB) early in the disease course with a depression in muscle protein synthesis (MPS), resulting in a net negative muscle protein balance $(6,8)$. MPS appears to increase with time while MPB remains constant, resulting in a less negative net protein balance (8). Although the exact pathophysiology is unclear, drivers of critical illness muscle wasting are likely multi-modal-an interaction between metabolic alterations and ICU therapy (9). Pro-inflammatory cytokines with sepsis (10), hyperglycemia (11), sedation and immobilization during mechanical ventilation (11), and high corticosteroid dose (11) are some factors that can trigger MPB and/or suppress MPS.

It is unclear whether children experience similar MPS and MPB changes as that in adults. Like adults, children are also exposed to the aforementioned insults during critical illness (12). Yet, children differ in metabolism and body composition (13), suggesting differences in skeletal muscle turnover than adults. Understanding protein turnover in pediatric critical illness is an important step in reducing or preventing muscle loss. The aim of this narrative review was to explore the evidence for muscle wasting in critically ill children through pathophysiology of muscle wasting and existing pediatric literature on muscle protein homeostasis. We present the following article in accordance with the Narrative Review reporting checklist (available at http:// dx.doi.org/10.21037/tp-20-298).

\section{Methods}

Medline, Embase and the Cumulative Index to Nursing and Allied Health Literature (CINAHL) databases were searched from the earliest available dates up until June 2020. Keywords and major subject headings used in combination included: "skeletal muscle"; "muscle protein synthesis", "muscle protein degradation", "protein metabolism"; "growth and development", "nutrition", "immobility”, “exercise”, "disease”, "critical illness". Results were limited to full articles and those pertaining to children (0-18 years). Conference abstracts and those pertaining to neuromuscular disease were excluded. After accounting for duplicates, titles abstracts were scanned and full articles were retrieved for shortlisted papers. Additional relevant studies were identified from hand-searching of reference lists of the shortlisted articles.

\section{Muscle protein turnover}

The process of muscle protein homeostasis, summarized in Figure 1, is well known and has been detailed elsewhere $(14,15)$. Briefly, muscle growth or atrophy is determined by the net balance of MPS and MPB. When MPS exceeds $\mathrm{MPB}$, there is a resultant net positive balance and muscle accretion occurs, whereas atrophy occurs when MPB exceeds MPS. MPS is energy dependent, controlled by various pathways which centers around the mammalian target of rapamycin (mTOR) and Protein Kinase B (Akt) (16). One of the major pathways for MPS is referred to as the Insulin-like Growth Factor 1/Phosphotidylionositol-3-kinase/Protein kinase B (IGF-1/PI3K/AKT) pathway, although anabolism can also occur via direct activation of mTOR by amino acids $(15,17,18)$. Various upstream factors including IGF-1 and amino acids, activate Akt and mTOR, which in turn signal the three groups of proteins: Eukaryotic Initiation Factors (EIFs), Eukaryotic Elongation Factors (EEFs) and Eukaryotic Release Factors (ERFs) to carry out initiation, elongation and termination respectively (15).

MPB occurs mainly via the Ubiquitin Proteasome Pathway (UPP), and to a smaller extent the lysosomal and calpain proteolytic pathways $(19,20)$. The UPP can be activated by phosphorylation of AKT, resulting in FOXO translocation to the nucleus upregulating ubiquitin ligases. Two ubiquitin ligases found responsible for increased UPP activity are the Muscle Ring Finger 1 (Murf-1) and the atrogin-1/F-box component (MAFbx). Of note, AKT independent activation can occur via NFkB, likely downstream of TNF superfamily receptors (21).

During critical illness, many factors upregulate MPB or inhibit MPS, or both. Risk factors associated 


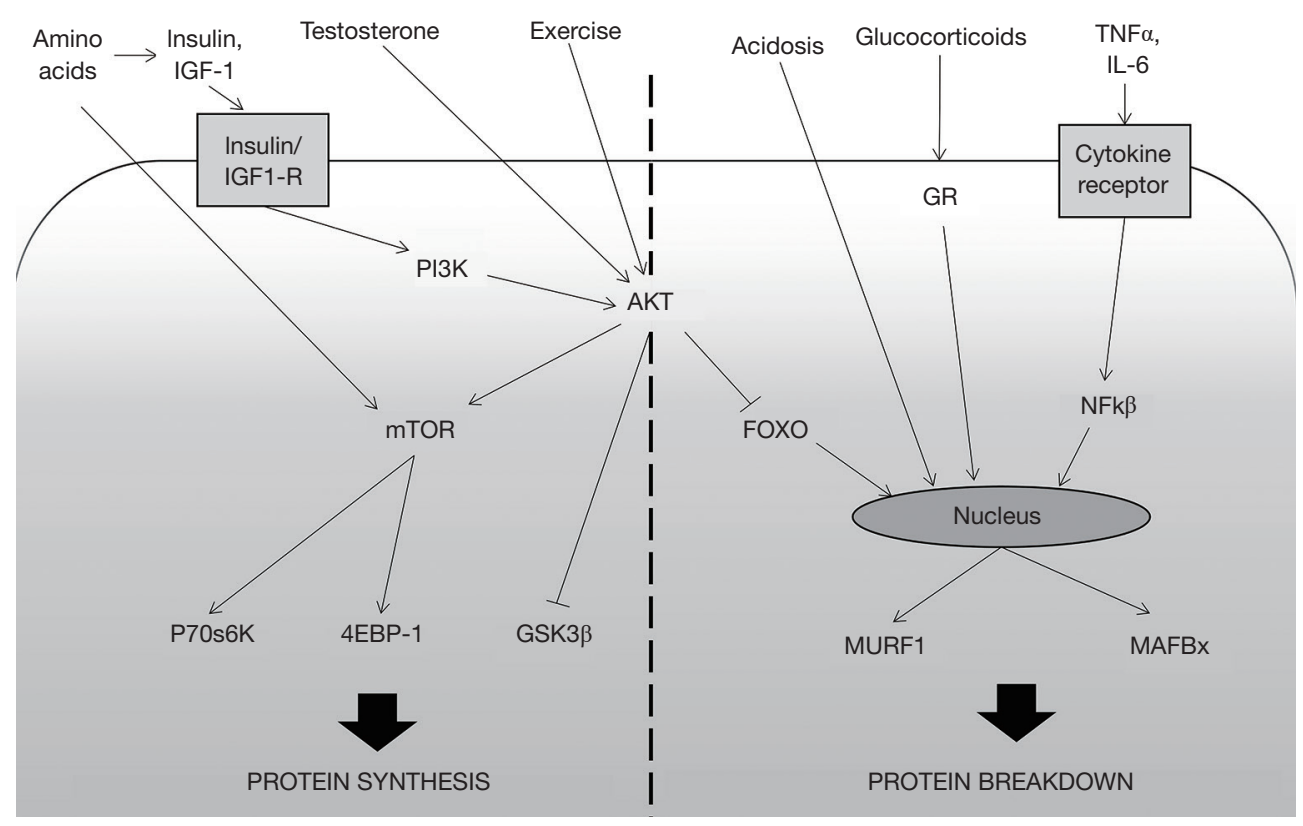

Figure 1 Simple depiction of muscle protein synthesis and breakdown pathways. On the left of the image are factors promoting muscle protein synthesis, on the right are factors promoting muscle protein breakdown (6). 4EBP-1, 4E binding protein 1; AKT, protein kinase B; FOXO, forkhead box O; GR, glucocorticoid receptor; GSK3 $\beta$, glycogen synthase kinase 3 beta; IGF-1, insulin-like growth factor 1; IGF1-R, insulin-like growth factor receptor; IL-6, interleukin 6; MURF1, muscle ring finger 1; MAFBx, muscle atrophy F-box/atrogin-1; mTOR, mammalian target of rapamycin; NFк $\beta$, nuclear factor kappa beta; PI3K, phophoinositide 3-kinase; p70s6K, p70 s6 kinase; TNF $\alpha$, tumor necrosis factor alpha.

with ICU muscle wasting include sepsis $(10,11)$, organ dysfunction (11), mechanical ventilation (11), acute lung injury (6), hyperglycemia (22) and high corticosteroid dose (11). Sepsis results in the release of pro-inflammatory cytokines and oxidizing free radicals, which have been shown to upregulate production of Murf-1 (23) and inhibit MPS via decreased phosphorylation of mTOR and downstream eukaryotic initiation factors (24). Patients are typically mechanically ventilated, sedated and immobilized, reducing the mechanical load on the muscle, which can in turn upregulate MPB and decrease MPS resulting in disuse atrophy (25). The mechanistic processes are described further in following sections. However, interventions focusing on appropriate sedation dose and duration, as well as early mobilization, have shown promising results to counter this $(26,27)$. Hyperglycemia likely increases muscle breakdown via caspase proteolysis and UPP (28), while corticosteroid use has been associated with increased ubiquitin mRNA encoding and higher Murf-1 and MAFbx expression (29).

Direct measurements of MPS usually involve stable isotope infusions followed by skeletal muscle biopsy to determine the isotope incorporation rate (30). This is usually done in conjunction with measuring muscle protein balance across a limb via blood flow, and estimating limb MPB via tracer dilution (31). Molecular drivers of MPS and breakdown, e.g. mTOR, Murf-1 and MAFbx, have also been used to identify cellular pathways and mechanisms for muscle protein turnover $(6,32)$, though no single protein currently serves as a good marker for protein turnover $(6,33)$. Due to these limitation, isotope incorporation studies have mostly been conducted in animals $(34,35)$, a major constraint in their generalizability.

As such, whole body protein turnover studies have been used to extrapolate muscle protein turnover (Table 1) (36). Nitrogen balance has been traditionally used to reflect whole body protein balance, but can be inaccurate due to methodological limitations and physiological instabilities (37). More recently, the accuracy has improved using stable isotope studies (37). However, the proportion of whole body protein turnover that is attributable to muscle varies depending on metabolic state, and thus whole body protein turnover may not be accurate reflection of MPS in critical illness $(36,38)$. Nevertheless, together with 
Table 1 Methods used to study muscle protein turnover

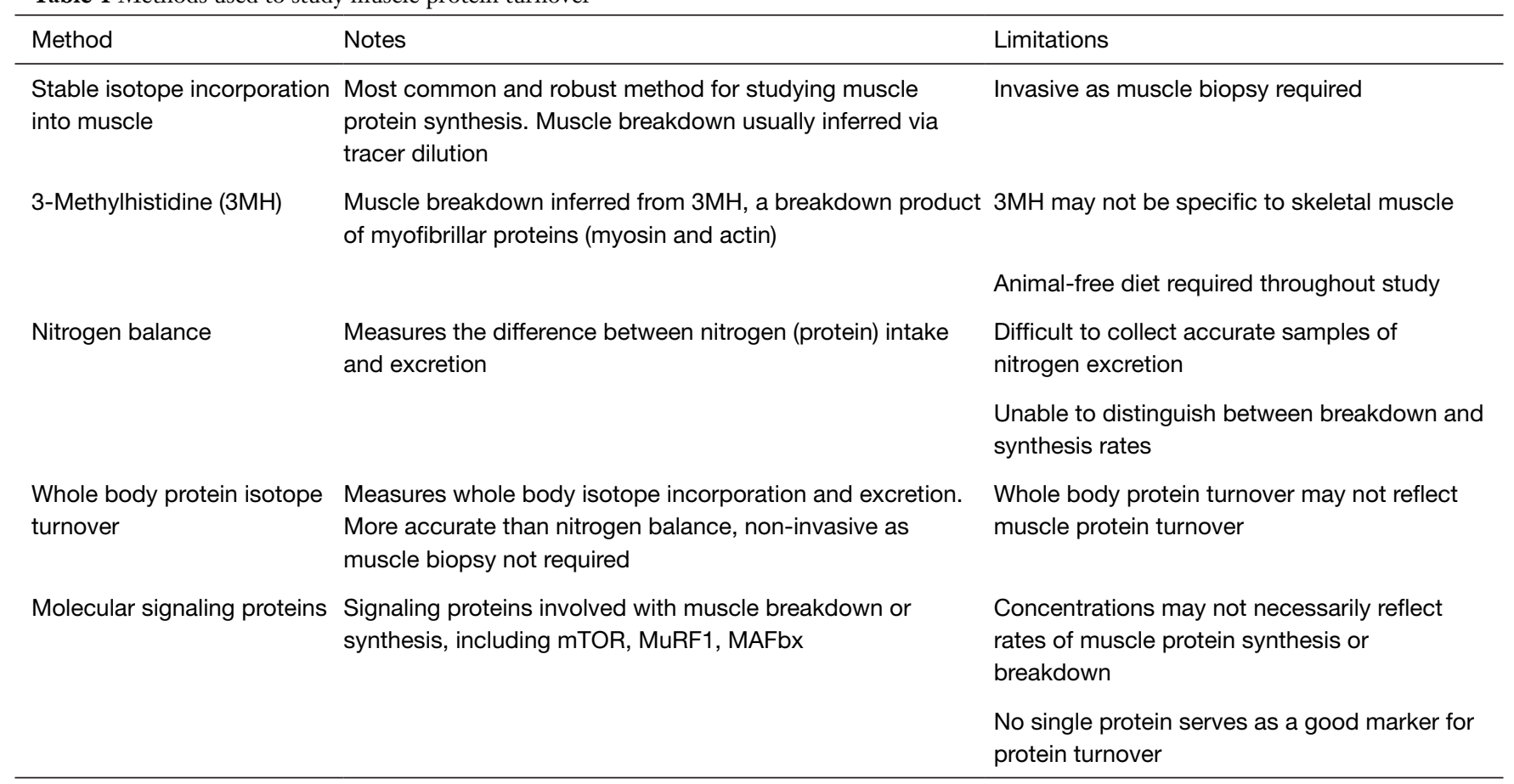

mTOR, mammalian target of rapamycin; MuRF1, muscle ring finger 1; MAFbx, atrogin-1/F-box component.

observations from healthy children and children with noncritical illness, these protein turnover studies provide some insight to possible mechanisms driving muscle turnover in critically ill children.

\section{MPS and breakdown in healthy children}

Growth in healthy well-fed infants is rapid, where MPS and MPB are highest $(34,39)$. Isotope incorporation studies show that MPS rates in rats are highest at birth and fall to a third at weaning, then a further 5-6 times to reach adult levels $(35,39)$. Decreasing MPS rates with age has been attributed to declining growth factors and resistance to anabolic agents (40). MPB is also high during rapid growth presumably to allow for muscle remodeling, decreasing at a slower rate than that of MPS from infancy to adulthood $(39,41)$. The exception to this is during puberty, where whole body protein turnover using $\left[1-{ }^{13} \mathrm{C}\right]$ leucine tracer showed significantly lower proteolysis in pubertal children compared to pre-pubertal children while whole body protein synthesis rates were similar or slightly decreased $(42,43)$. Lower proteolysis may be explained by the higher concentrations of growth promoters (e.g., insulin, IGF1) in pubertal children $(42,43)$. The net positive balance throughout childhood results in continuous muscle deposition, until MPB and MPS eventually reach an equilibrium after puberty, resulting in stable adult levels $(39,44)$. During these stages, various factors can influence muscle protein turnover (Table 2).

\section{Growth factors and hormones}

Differences in muscle protein turnover during different stages of infancy, childhood and adolescence may be partially explained by growth factors including growth hormone (GH) and IGF-1. IGF-1 levels are low in infancy, rising steadily and peaking during puberty, decreasing after $(91,92)$. GH levels follow a similar trend and are generally higher in pubertal children than in pre-pubertal children or adults (93). Their necessity for muscle growth is evident in that both IGF-1 and GH knockout mice have consistently retarded growth and reduced muscle mass (94). Such effect is also seen in children with GH and IGF-1deficiency (95), which improves after exogenous GH therapy (96).

IGF-1 stimulates MPS mainly through the IGF-1 receptor and activation of $\mathrm{PI} 3 \mathrm{~K}$ and AKT, which subsequently phosphorylates mTOR and GSK3B MPS pathways while inhibiting MPB $(97,98)$. GH appears to 
Table 2 Skeletal muscle protein synthesis and breakdown in response to various factors

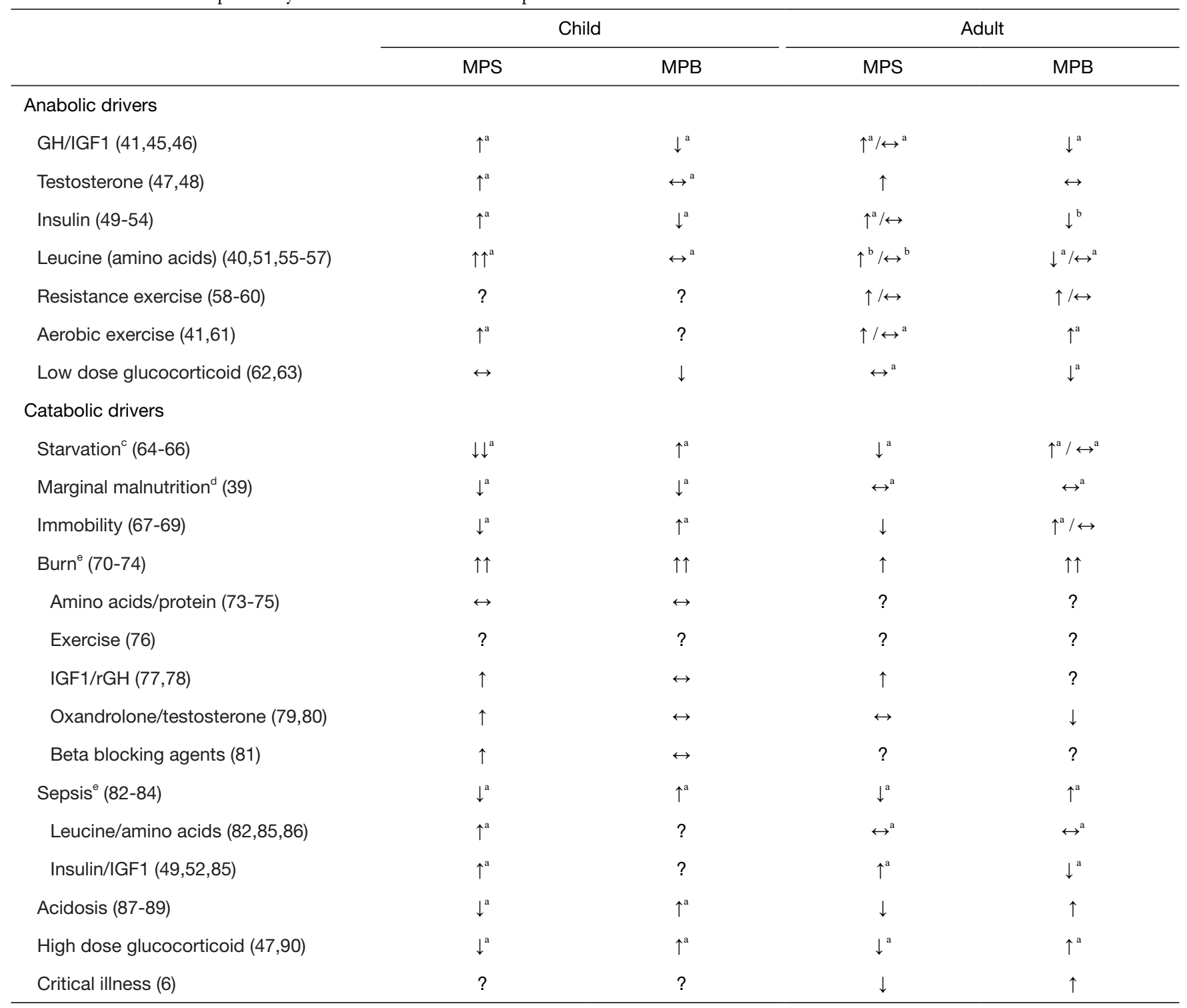

$\uparrow$, Increased; $\downarrow$, decreased; $\leftrightarrow$, no change; ?, unclear or no evidence; GH, growth hormone; IGF1, insulin-like growth factor 1; rGH, recombinant growth hormone; MPS, muscle protein synthesis; MPB, muscle protein breakdown. Studies are human studies except as specified: ${ }^{a}$, animal studies; ' , animal and human studies; ${ }^{c}$, Starvation is defined as complete food deprivation; ${ }^{\mathrm{d}}$, marginal malnutrition is defined as an intake that may be sufficient for maintenance, but insufficient for growth; ${ }^{\text {e }}$, Sub-points demonstrate effects that are in addition to that observed in the major factor.

act by stimulating IGF-1 mRNA expression, but also independently by increasing myotube size via cell fusion $(96,99)$. The complete anabolic pathway of GH is unclear and still being studied (100).

GH and IGF-1 are also important for puberty, both in the onset of as well as growth during puberty $(101,102)$. Higher IGF-1 concentrations were observed in pubertal children which corresponded with leucine retention, and may explain the lower proteolysis seen in pubertal children $(42,43)$. GH and IGF-1 promotes protein synthesis while inhibiting fat deposition (101), promotes cartilage and bone formation for linear growth (101), and interacts with sex steroid hormones to amplify their action during puberty (103). In addition, sex steroid hormones are also an independent determinant 
of muscle mass-male pubertal rats given testosterone have greater muscle growth; hypogonadal adolescent boys experience an increased muscle mass after testosterone administration $(101,104)$. Testosterone appears to increase satellite cell numbers and muscle fiber size (105). In females, the opposite is seen as estrogen and progesterone appear to inhibit MPS in pubertal ovariectomized rats (106). Increased MPS may instead be due to the indirect action of estrogen stimulating GH production $(44,107)$. Higher GH, IGF-1 and sex steroid hormones in males released during puberty are likely responsible for greater muscle deposition compared to females (102).

Adults may be less responsive to growth hormones and factors than in children. Provision of GH does not consistently activate MPS, particularly in the elderly $(108,109)$. Although GH administration was able to increase MPS in young men, GH was unable to increase IGF-1, MPS rates, or muscle fiber size in elderly men $(108,109)$.

\section{Nutrition}

Nutrition is crucial in maintaining muscle mass, demonstrated by animal feeding and starvation models $(65,82)$. Feeding increases amino acid levels, thus stimulating MPS $(49,110)$. This stimulatory effect appears to be primarily achieved by the branched-chain amino acid (BCAA) leucine, but not valine, isoleucine or non-BCAAs $(56,111)$. However, leucine action is still dependent on total amino acid availability, as leucine supplementation alone could not stimulate MPS in starved piglets unless amino acids were infused concurrently (112).

Feeding also activates MPS and inhibits MPB via insulin release, which is best achieved with pulse feeding instead of a constant provision of nutrients, as shown by the inability for continuous feeding to stimulate insulin and amino acid increases in neonatal piglets $(50,51)$. However, a recent trial in critically ill adults found that bolus feeding was not more protective against muscle wasting than continuous feeding (113). Conversely, insulin resistance inhibits MPS and lean body mass accretion as shown by dual-energy X-ray absorptiometry (DXA) (114).

The response to nutrition also appears to be agedependent. Ten-day-old pigs exhibited higher post-prandial MPS rates than 28-day-old pigs (115), while some elderly rats and humans showed no evident change in MPS $(40,57)$. These attenuations are hypothesized to be due to several factors, including decreased sensitivity to amino acids and lower insulin production with feeding $(35,57)$, a drop in activation of insulin receptors in skeletal muscle (34), and decreased MPS signaling proteins with age (40). Similarly, starvation resulted in rapid inhibition of MPS and upregulation of MPB in newborn and young animals, while less drastic changes were observed in adult animals (64-66). With marginal malnutrition, decreases in both MPB and MPS were evident in young, but not adult rats (39). Fortunately, these decreases in MPS were reversed after nutritional rehabilitation (39). Collectively, these emphasize the dependence of muscle homeostasis and growth on nutrition in the young.

\section{Immobility and exercise}

Immobility in adults results in downregulation of MPS without change in MPB $(68,69)$, while in young rats both downregulation of MPS and upregulation of MPB occur (67). Unloading of hind limb in infant rats for 3 months resulted in a smaller soleus leg muscle fiber size than controls despite reloading, implying long-term deficits in muscle mass (116).

Resistance exercise improves MPS and muscle protein balance in adults $(59,60)$. However, muscle hypertrophy is thought to occur only in the presence of androgens, which occurs in early and late adolescence (117). In prepubertal children, muscle strength improvements may result from neurological adaptations instead of muscle size changes. Pre-pubescent boys who underwent resistance training for 5 months experienced increases in strength independent of changes in muscle cross sectional area (118). Increases in upper-arm and mid-thigh strength were more closely correlated with improved motor skill coordination and motor unit activation (118). In contrast, rat models demonstrate that aerobic exercise appears to have a greater anabolic effect in the young (41).

Nutrition is also important in exercise associated protein homeostasis, as essential amino acids attenuated MPB and enhanced MPS after resistance exercise in adults (58). In children, whole body $\left[{ }^{15} \mathrm{~N}\right]$ glycine tracer protein turnover studies suggest similar effects as intake of protein or protein-containing food has been shown to improve protein balance in children after exercise (119).

\section{Alterations of muscle protein homeostasis in disease states}

\section{Burns}

In disease states, muscle turnover in children is altered 
due to a variety of factors. Muscle protein turnover studies utilizing isotope incorporation with muscle biopsy in disease states are rare and mostly limited to children with burns. Several isotope tracer turnover studies using [ring${ }^{13} \mathrm{C}_{6}$ ]phenylalanine accompanied by vastus lateralis biopsy have been conducted in children with severe burn injuries $(70,71,79)$. Burn injury results in a state of inflammation characterized by high inflammatory cytokine concentrations such as TNF- $\alpha$ and IL-6 (120), which can trigger MPB pathways via NFKB activation (121). Phenylalanine tracer studies demonstrate increased muscle breakdown in the leg immediately post burn (1-2 weeks), which continues to increase and peak at 4 weeks post burn before falling to approach normal levels after 2 years (70,71). MPS follows a similar pattern $(70,71)$, and the net muscle protein balance depends on several factors including burn size and degree, sepsis, time to excisional treatment, age and gender $(70,122)$. Muscle wasting and loss of lean body mass can continue up to even after 9 months post injury (123). Similar hypermetabolic responses have been reported in adults with burn injury (124).

Therapies to reduce catabolism in burned children include nutrition, exercise therapy, anabolic agents and beta blocking agents $(76,79,81,125)$. Although supplemental whey protein improved weight gain and plasma amino acid levels in children 1.5 months after major burn (125), [13C6] phenylalanine incorporation studies show that immediately post-burn, high dietary protein in children increased protein synthesis of the skin but not muscle, suggesting a prioritization of wound healing over preservation of muscle (74). Similarly, provision of intravenous amino acids were unable to significantly increase MPS across the leg 6 months post-burn $(73,75)$, although this was possibly due to small sample sizes.

A combination of resistance and aerobic exercise for 12 -weeks significantly improved muscle strength and lean body mass gain in burned children as shown by DXA (76). However, whether this was due to an attenuation of MPB or increased MPS is unclear. MPS rates by $\left[\mathrm{ring}^{2}{ }^{2} \mathrm{H}_{5}\right.$ ] phenylalanine isotope incorporation were not significantly higher than in controls, although this could be because MPS was not measured immediately but at $\geq 48$ hours postexercise (76).

Exogenous anabolic agents appear to ameliorate catabolism in children with burns by modulating MPS. Short-term provision of IGF1 and beta-blockers following major burns were able to stimulate MPS $(77,81)$, while recombinant human $\mathrm{GH}$ increased lean body mass
$(126,127)$. Oxandrolone administered soon after burn injury also increased MPS and net muscle protein balance (79), the anabolic effect being greater when combined with aerobic and resistance exercise (123). Provision of oxandrolone for a year post-burn continued to aid lean body mass accrual for up to 5 years as shown on DXA scans, although this only occurred in children above 7 years, possibly as they were less anabolic than younger children $(123,128,129)$.

\section{Sepsis, glucocorticoids and acidosis}

Dysregulations in the GH/IGF-1 axis have been observed in critically ill patients. In a cohort of children with sepsis or trauma, levels of IGF-1 were lower and levels of GH were higher than those in healthy children (130). The increased GH was thought to be a response to the increase in inflammatory cytokines produced during critical illness, as well as a lack of feedback inhibition from the depressed IGF-1 levels, creating a state of GH resistance. In another cohort of critically ill children with sepsis, study authors found that GH concentrations were higher and IGF-1 concentrations were lower in non-survivors compared to survivors, suggesting that this dysregulation was predictive of mortality (131). However, it is unclear how this dysregulation translates to protein turnover in critically ill children.

Age-different responses have also been observed in sepsis-induced animal models (83). Sepsis has been shown to decrease MPS due to reduced mRNA translation of anabolic signaling (132), while MPB remains high through upregulation of ubiquitin ligases MuRF1 and MAFbx (121). The increase in MuRF1 and MAFbx during sepsis is greater in older than young animals (83). In response to feeding, MPS is increased in septic neonatal (131) but not adult animals (83), further suggesting that the young may be more sensitive to stimulants of MPS than adults.

The role of glucocorticoids in pediatric muscle protein turnover appears equivocal, and possibly dependent on dose and the condition in which muscle wasting occurs (133). Glucocorticoids are thought to independently increase MPB by upregulating expression of FOXO, MuRF1 and MAFbx (134), as well as reducing MPS through inhibiting amino acid and IGF-1 production, and suppressing mTOR signaling $(135,136)$. Glucocorticoids also appear to be necessary for sepsis and tumor induced MPB, as Murf-1 and MAFbx mRNA levels are not significantly increased in young animal models where glucocorticoid receptors were blocked or knocked-out $(121,137)$. High dose steroids 
upregulated MPB and downregulated MPS in young rats (90), and have been associated with increased protein breakdown and decreased synthesis in children with Crohn's disease (138). High dose steroid use has also been associated with myopathy in pediatric asthma (139). However, low dose glucocorticoids prevented muscle atrophy through suppression of Akt/FOXO inhibition and blunting of lysosomal protein breakdown in adult rats (63). Low-dose glucocorticoids have also been shown to decrease MPB (without change in MPS), with accompanying increases in muscle mass and strength in boys with Duchenne muscular dystrophy (62).

The presence of acidosis has also been shown to affect protein homeostasis in children with chronic renal failure (140). Whole body protein turnover studies in children with chronic kidney disease (CKD) demonstrate breakdown increased with the severity of acidosis, while whole body protein synthesis was comparable (140). Although whole body protein turnover is not necessarily reflective of muscle protein turnover, metabolic acidosis has shown to increase MPB in adults with CKD (87). Muscle mass visualized by peripheral quantitative computed tomography and DEXA have also been found to be reduced in CKD children (5-21 years) compared to healthy children, with muscle deficits that correlated with the severity of CKD $(141,142)$.

\section{Further research needed for clinical translation}

Critically ill children, like adults, are exposed to many risk factors for muscle wasting [e.g., sepsis (12), hyperglycemia (143), malnutrition (144) and high dose, prolonged corticosteroid use (145)]. Factors upregulating MPB, such as starvation, immobility and burns, appear to impact the young more than adults. The young are also more dependent on growth factors for muscle maintenance and growth than adults, suggesting that children may be more susceptible to muscle wasting than adults in the presence of critical illness-related starvation and immobility, especially during periods of rapid growth (i.e., infancy and puberty). Yet, children have proportionally fewer type 2 muscle fibers (146), which may be preferentially targeted in ICU muscle wasting (9), possibly resulting in less muscle wasting. The young also appear to be more responsive to anabolic agents and resilient to catabolism during sepsis and burns $(34,72)$. Yet, whole body turnover studies have not demonstrated consistent evidence of improved protein balance with increased protein provision in critically ill children, possibly affected by other factors regulating protein turnover such as degree of inflammation $(147,148)$. Unfortunately, without actual studies on muscle protein turnover, it is difficult to conclude the effect critical illness has on muscle in children.

In addition, of greater clinical relevance would be the effect of muscle wasting on health and outcomes of pediatric critical care survivors, and whether muscle wasting results in persistent impairment in function and strength as observed in adults (5). Muscle wasting due to major burns can result in loss of strength, power and aerobic capacity in children (76). Prolonged muscle loss can also reduce bone mineral content and limit growth potential through lowered mechanical load that the bone is exposed to (149), as observed in children with CKD (142). Pediatric intensivists are increasingly aware of morbidities following critical illness and are beginning to study the effect of critical illness on long-term outcomes (150). Physical limitations have been reported in survivors of critical illness (150), and body composition at PICU admission has been associated with functional impairment at discharge (151), but whether functional impairment is associated with muscle wasting in critically ill children has yet to be determined.

The limited evidence of muscle wasting in critically ill children is largely due to the methods currently available in studying muscle protein turnover. Less invasive and complex methods of identifying muscle wasting would be beneficial. Generalized weight loss and reduced mid upper arm circumference have been commonly reported in critically ill children. Losses in weight and mid-upper arm circumference correlated with lower energy and protein intakes, and were more evident in older than younger children, similar to children with burns $(12,72,144)$. However, weight and arm circumference losses may be influenced by edema or fat loss (144), and methods to assess skeletal muscle would help better inform musclespecific changes. Some methods used in adult ICUs include muscle mass visualization by ultrasonography, bioelectrical impedance analysis and tests of strength and physical function (hand grip strength, six-minute walk test) (5-7). A longitudinal study demonstrated loss in ultrasound-derived diaphragm and limb muscles thickness in critically ill children, which was greater in older children compared to younger children (152). Ultrasound, bioelectrical impedance analysis and strength and function testing are relatively simple and inexpensive tests that have just begun to be used in critically ill children (152-154), but demonstration of their validity in this population is needed. Research on muscle protein turnover has traditionally been restricted 
by the need for muscle tissue biopsies, which are invasive and thus difficult to obtain, especially in children. However, recent work in cancer cachexia patients seem to suggest the feasibility of using urine and serum for metabolomics research to understand the mechanistic pathways of muscle wasting $(155,156)$, which could potentially be translated to critical illness. Future studies using these methodologies and associating them with functional outcomes would further characterize the clinical significance of muscle changes in these children.

\section{Limitations}

Extrapolation of muscle protein homeostasis from animals and other pediatric populations to critically ill children may be too simplistic given differences in metabolism (157). Detailed consideration of factors such as dose and time-course of interventions across populations is needed. Furthermore, given the heterogeneity of critical illness, metabolic responses may vary depending on primary diagnosis, co-morbidities and illness severity. Generalizations from a specific patient group (e.g., burns) to the entire pediatric ICU cohort may be erroneous, and speculations of muscle wasting patterns may have to be tailored according to the risk factors observed in individual patients. Finally, we did not delve into the role of microRNAs or satellite cells as these were beyond the scope of this review, although their role in muscle homeostasis has been studied increasingly in recent years (14).

\section{Conclusions}

Factors influencing muscle protein turnover appear to be similar in adults and children, but baseline protein homeostasis and response to catabolic and anabolic stimuli may be different. Compared to adults, children are equally or more susceptible to muscle catabolism with starvation, burn injury and immobility. However, children, particularly young ones, appear to be more responsive to anabolic factors. Critically ill children experience muscle wasting, which may be reversible with the right anabolic interventions. Closer study of muscle protein turnover at various ages, time points of critical illness and response to therapies are needed in critically ill children.

\section{Acknowledgments}

Funding: None.

\section{Footnote}

Provenance and Peer Review: This article was commissioned by the editorial office, Translational Pediatrics for the series "Pediatric Critical Care". The article has undergone external peer review.

Reporting Checklist: The authors have completed the Narrative Review reporting checklist. Available at http:// dx.doi.org/10.21037/tp-20-298

Conflicts of Interest: All authors have completed the ICMJE uniform disclosure form (available at http://dx.doi. org/10.21037/tp-20-298). The series "Pediatric Critical Care" was commissioned by the editorial office without any funding or sponsorship. JHL served as the unpaid Guest Editor of the series and serves as an unpaid editorial board member of Translational Pediatrics from Nov 2019 to Nov 2021. The other authors have no conflicts of interest to declare.

Etbical Statement: The authors are accountable for all aspects of the work in ensuring that questions related to the accuracy or integrity of any part of the work are appropriately investigated and resolved.

Open Access Statement: This is an Open Access article distributed in accordance with the Creative Commons Attribution-NonCommercial-NoDerivs 4.0 International License (CC BY-NC-ND 4.0), which permits the noncommercial replication and distribution of the article with the strict proviso that no changes or edits are made and the original work is properly cited (including links to both the formal publication through the relevant DOI and the license). See: https://creativecommons.org/licenses/by-nc-nd/4.0/.

\section{References}

1. Manning JC, Pinto NP, Rennick JE, et al. Conceptualizing Post Intensive Care Syndrome in Children-The PICS-p Framework. Pediatr Crit Care Med 2018;19:298-300.

2. Herrup EA, Wieczorek B, Kudchadkar SR. Characteristics of postintensive care syndrome in survivors of pediatric critical illness: A systematic review. World J Crit Care Med 2017;6:124-34.

3. Wieczorek B, Ascenzi J, Kim Y, et al. PICU Up! Impact of a Quality Improvement Intervention to Promote Early Mobilization in Critically Ill Children. Pediatr Crit Care 
Med 2016;17:e559-66.

4. Choong K, Awladthani S, Khawaji A, et al. Early Exercise in Critically Ill Youth and Children, a Preliminary Evaluation: The wEECYCLE Pilot Trial*. Pediatr Crit Care Med 2017;18:e546-54.

5. Herridge MS, Tansey CM, Matté A, et al. Functional disability 5 years after acute respiratory distress syndrome. N Engl J Med 2011;364:1293-304.

6. Puthucheary ZA, Rawal J, McPhail M, et al. Acute skeletal muscle wasting in critical illness. JAMA 2013;310:1591600. Erratum in: JAMA 2014;311:625.

7. Ali NA, O'Brien JM Jr, Hoffmann SP, et al. Acquired weakness, handgrip strength, and mortality in critically ill patients. Am J Respir Crit Care Med 2008;178:261-8.

8. Gamrin-Gripenberg L, Sundström-Rehal M, Olsson D, et al. An attenuated rate of leg muscle protein depletion and leg free amino acid efflux over time is seen in ICU longstayers. Critical Care 2018;22:13.

9. Stevens RD, Marshall SA, Cornblath DR, et al. A framework for diagnosing and classifying intensive care unit-acquired weakness. Crit Care Med 2009;37:S299-308.

10. de Letter MA, Schmitz PI, Visser LH, et al. Risk factors for the development of polyneuropathy and myopathy in critically ill patients. Crit Care Med 2001;29:2281-6.

11. De Jonghe B, Sharshar T, Lefaucheur JP, et al. Paresis acquired in the intensive care unit: a prospective multicenter study. JAMA 2002;288:2859-67.

12. Delgado AF, Okay TS, Leone C, et al. Hospital malnutrition and inflammatory response in critically ill children and adolescents admitted to a tertiary intensive care unit. Clinics (Sao Paulo) 2008;63:357-62.

13. Kim J, Shen W, Gallagher D, et al. Total-body skeletal muscle mass: estimation by dual-energy X-ray absorptiometry in children and adolescents. Am J Clin Nutr 2006;84:1014.

14. Braun T, Gautel M. Transcriptional mechanisms regulating skeletal muscle differentiation, growth and homeostasis. Nat Rev Mol Cell Biol 2011;12:349-61.

15. Glass DJ. Skeletal muscle hypertrophy and atrophy signaling pathways. Int J Biochem Cell Biol 2005;37:1974-84.

16. Kimball SR, Jefferson LS. Control of Translation Initiation through Integration of Signals Generated by Hormones, Nutrients, and Exercise. J Biol Chem 2010;285:29027-32.

17. Cai D, Frantz JD, Tawa NE Jr, et al. IKKbeta/NF-kappaB activation causes severe muscle wasting in mice. Cell 2004;119:285-98.

18. McCarthy JJ, Esser KA. Anabolic and catabolic pathways regulating skeletal muscle mass. Curr Opin Clin Nutr Metab Care 2010;13:230-5.

19. Biolo G, Bosutti A, Iscra F, et al. Contribution of the ubiquitin-proteasome pathway to overall muscle proteolysis in hypercatabolic patients. Metabolism 2000;49:689-91.

20. Mansoor O, Beaufrere B, Boirie $Y$, et al. Increased mRNA levels for components of the lysosomal, $\mathrm{Ca} 2+$-activated, and ATP-ubiquitin-dependent proteolytic pathways in skeletal muscle from head trauma patients. Proc Natl Acad Sci U S A 1996;93:2714-8.

21. Dogra C, Changotra H, Wedhas N, et al. TNF-related weak inducer of apoptosis (TWEAK) is a potent skeletal muscle-wasting cytokine. FASEB J 2007;21:1857-69.

22. Hermans G, Wilmer A, Meersseman W, et al. Impact of intensive insulin therapy on neuromuscular complications and ventilator dependency in the medical intensive care unit. Am J Respir Crit Care Med 2007;175:480-9.

23. Files DC, D'Alessio FR, Johnston LF, et al. A critical role for muscle ring finger-1 in acute lung injury-associated skeletal muscle wasting. Am J Respir Crit Care Med 2012;185:825-34.

24. Schefold JC, Bierbrauer J, Weber-Carstens S. Intensive care unit-acquired weakness (ICUAW) and muscle wasting in critically ill patients with severe sepsis and septic shock. J Cachexia Sarcopenia Muscle 2010;1:147-57.

25. Jackman RW, Kandarian SC. The molecular basis of skeletal muscle atrophy. Am J Physiol Cell Physiol 2004;287:C834-43.

26. Schweickert WD, Pohlman MC, Pohlman AS, et al. Early physical and occupational therapy in mechanically ventilated, critically ill patients: a randomised controlled trial. Lancet 2009;373:1874-82.

27. Papazian L, Forel JM, Gacouin A, et al. Neuromuscular Blockers in Early Acute Respiratory Distress Syndrome. N Engl J Med 2010;363:1107-16.

28. Du J, Wang X, Miereles C, et al. Activation of caspase-3 is an initial step triggering accelerated muscle proteolysis in catabolic conditions. J Clin Invest 2004;113:115-23.

29. Gonnella P, Alamdari N, Tizio S, et al. C/EBPbeta regulates dexamethasone-induced muscle cell atrophy and expression of atrogin-1 and MuRF1. J Cell Biochem 2011;112:1737-48.

30. Rennie MJ. Muscle protein turnover and the wasting due to injury and disease. Br Med Bull 1985;41:257-64.

31. Chinkes DL. Methods for measuring tissue protein breakdown rate in vivo. Curr Opin Clin Nutr Metab Care 2005;8:534-7. 
32. Llano-Diez M, Renaud G, Andersson M, et al. Mechanisms underlying ICU muscle wasting and effects of passive mechanical loading. Critical care 2012;16:R209.

33. Greenhaff PL, Karagounis LG, Peirce N, et al. Disassociation between the effects of amino acids and insulin on signaling, ubiquitin ligases, and protein turnover in human muscle. Am J Physiol Endocrinol Metab 2008;295:E595-604.

34. Suryawan A, Nguyen HV, Bush JA, et al. Developmental changes in the feeding-induced activation of the insulinsignaling pathway in neonatal pigs. Am J Physiol Endocrinol Metab 2001;281:E908-15.

35. Davis TA, Fiorotto ML, Nguyen HV, et al. Enhanced response of muscle protein synthesis and plasma insulin to food intake in suckled rats. Am J Physiol 1993;265:R334-40.

36. Deutz NE, Wagenmakers AJ, Soeters PB. Discrepancy between muscle and whole body protein turnover. Curr Opin Clin Nutr Metab Care 1999;2:29-32.

37. Welle S. Human Protein Metabolism. New York, NY: Springer, 1999.

38. Prelack K, Yu YM, Dylewski M, et al. The Contribution of Muscle to Whole Body Protein Turnover Throughout the Course of Burn Injury in Children. J Burn Care Res 2010;31:942-8.

39. Millward DJ, Garlick PJ, Stewart RJ, et al. Skeletal-muscle growth and protein turnover. Biochem J 1975;150:235-43.

40. Cuthbertson D, Smith K, Babraj J, et al. Anabolic signaling deficits underlie amino acid resistance of wasting, aging muscle. FASEB J 2005;19:422-4.

41. Willis PE, Chadan S, Baracos V, et al. Acute exercise attenuates age-associated resistance to insulin-like growth factor I. Am J Physiol 1997;272:E397-404.

42. Arslanian SA, Kalhan SC. Protein turnover during puberty in normal children. Am J Physiol 1996;270:E79-84.

43. Beckett PR, Jahoor F, Copeland KC. The Efficiency of Dietary Protein Utilization Is Increased during Puberty 1. J Clin Endocrinol Metab 1997;82:2445-9.

44. Veldhuis JD, Roemmich JN, Richmond EJ, et al. Endocrine Control of Body Composition in Infancy, Childhood, and Puberty. Endocr Rev 2005;26:114-46.

45. Frampton RJ, Jonas HA, MacMahon RA, et al. Failure of IGF-1 to affect protein turnover in muscle from growthretarded neonatal rats. J Dev Physiol 1990;13:125-33.

46. Brioche T, Kireev RA, Cuesta S, et al. Growth hormone replacement therapy prevents sarcopenia by a dual mechanism: improvement of protein balance and of antioxidant defenses. J Gerontol A Biol Sci Med Sci
2014;69:1186-98.

47. Yin HN, Chai JK, Yu YM, et al. Regulation of signaling pathways downstream of IGF-I/insulin by androgen in skeletal muscle of glucocorticoid-treated rats. J Trauma 2009;66:1083-90.

48. Smith GI, Yoshino J, Reeds DN, et al. Testosterone and progesterone, but not estradiol, stimulate muscle protein synthesis in postmenopausal women. J Clin Endocrinol Metab 2014;99:256-65.

49. Orellana RA, Kimball SR, Suryawan A, et al. Insulin stimulates muscle protein synthesis in neonates during endotoxemia despite repression of translation initiation. Am J Physiol Endocrinol Metab 2007;292:E629-36.

50. O'Connor PM, Bush JA, Suryawan A, et al. Insulin and amino acids independently stimulate skeletal muscle protein synthesis in neonatal pigs. Am J Physiol Endocrinol Metab 2003;284:E110-9.

51. Capel F, Prod'Homme M, Béchet D, et al. Lysosomal and proteasome-dependent proteolysis are differentially regulated by insulin and/or amino acids following feeding in young, mature and old rats. J Nutr Biochem 2009;20:570-6.

52. Vary TC, Dardevet D, Grizard J, et al. Differential regulation of skeletal muscle protein turnover by insulin and IGF-I after bacteremia. Am J Physiol 1998;275:E584-93.

53. Abdulla H, Smith K, Atherton PJ, et al. Role of insulin in the regulation of human skeletal muscle protein synthesis and breakdown: a systematic review and meta-analysis. Diabetologia 2016;59:44-55.

54. Hasselgren PO, Warner BW, James JH, et al. Effect of insulin on amino acid uptake and protein turnover in skeletal muscle from septic rats: evidence for insulin resistance of protein breakdown. Arch Surg 1987;122:228-33.

55. Boutry C, El-Kadi SW, Suryawan A, et al. Leucine pulses enhance skeletal muscle protein synthesis during continuous feeding in neonatal pigs. Am J Physiol Endocrinol Metab 2013;305:E620-31.

56. Escobar J, Frank JW, Suryawan A, et al. Regulation of cardiac and skeletal muscle protein synthesis by individual branched-chain amino acids in neonatal pigs. Am J Physiol Endocrinol Metab 2006;290:E612-21.

57. Dardevet D, Sornet C, Bayle G, et al. Postprandial stimulation of muscle protein synthesis in old rats can be restored by a leucine-supplemented meal. J Nutr 2002;132:95-100.

58. Børsheim E, Tipton KD, Wolf SE, et al. Essential amino 
acids and muscle protein recovery from resistance exercise. Am J Physiol Endocrinol Metab 2002;283:E648-57.

59. Mayhew DL, Kim JS, Cross JM, et al. Translational signaling responses preceding resistance training-mediated myofiber hypertrophy in young and old humans. J Appl Physiol (1985) 2009;107:1655-62.

60. Phillips SM, Tipton KD, Aarsland A, et al. Mixed muscle protein synthesis and breakdown after resistance exercise in humans. Am J Physiol 1997;273:E99-107.

61. Carraro F, Hartl WH, Stuart CA, et al. Whole body and plasma protein synthesis in exercise and recovery in human subjects. Am J Physiol 1990;258:E821-31.

62. Rifai Z, Welle S, Moxley Iii RT, et al. Effect of prednisone on protein metabolism in Duchenne dystrophy. Am J Physiol 1995;268:E67-74.

63. Crossland H, Constantin-Teodosiu D, Greenhaff PL, et al. Low-dose dexamethasone prevents endotoxaemiainduced muscle protein loss and impairment of carbohydrate oxidation in rat skeletal muscle. J Physiol 2010;588:1333-47.

64. Halevy O, Geyra A, Barak M, et al. Early posthatch starvation decreases satellite cell proliferation and skeletal muscle growth in chicks. J Nutr 2000;130:858-64.

65. Shavlakadze T, Soffe Z, Anwari T, et al. Short-term feed deprivation rapidly induces the protein degradation pathway in skeletal muscles of young mice. J Nutr 2013;143:403-9.

66. Goodman MN, McElaney MA, Ruderman NB. Adaptation to prolonged starvation in the rat: curtailment of skeletal muscle proteolysis. Am J Physiol 1981;241:E321-7.

67. Loughna P, Goldspink G, Goldspink DF. Effect of inactivity and passive stretch on protein turnover in phasic and postural rat muscles. J Appl Physiol 1986;61:173.

68. Wall BT, Snijders T, Senden JMG, et al. Disuse impairs the muscle protein synthetic response to protein ingestion in healthy men. J Clin Endocrinol Metab 2013;98:4872-81.

69. Symons TB, Sheffield-Moore M, Chinkes DL, et al. Artificial gravity maintains skeletal muscle protein synthesis during 21 days of simulated microgravity. J Appl Physiol (1985) 2009;107:34-8.

70. Diaz EC, Herndon DN, Lee J, et al. Predictors of muscle protein synthesis after severe pediatric burns. J Trauma Acute Care Surg 2015;78:816-22.

71. Chao T, Herndon DN, Porter C, et al. Skeletal muscle protein breakdown remains elevated in pediatric burn survivors up to one-year post-injury. Shock 2015;44:397-401.

72. Tuvdendorj D, Chinkes DL, Zhang XJ, et al. Adult patients are more catabolic than children during acute phase after burn injury: a retrospective analysis on muscle protein kinetics. Intensive Care Med 2011;37:1317-22.

73. Porter C, Cotter M, Diaz EC, et al. Amino acid infusion fails to stimulate skeletal muscle protein synthesis up to 1 year after injury in children with severe burns. J Trauma Acute Care Surg 2013;74:1480-5.

74. Patterson BW, Nguyen T, Pierre E, et al. Urea and protein metabolism in burned children: Effect of dietary protein intake. Metabolism 1997;46:573-8.

75. Tuvdendorj D, Chinkes DL, Zhang XJ, et al. Skeletal muscle is anabolically unresponsive to an amino acid infusion in pediatric burn patients 6 months postinjury. Ann Surg 2011;253:592-7.

76. Hardee JP, Porter C, Sidossis LS, et al. Early rehabilitative exercise training in the recovery from pediatric burn. Med Sci Sports Exerc 2014;46:1710-6.

77. Herndon DN, Ramzy PI, DebRoy MA, et al. Muscle protein catabolism after severe burn: effects of IGF-1/ IGFBP-3 treatment. Ann Surg 1999;229:713-20.

78. Debroy MA, Wolf SE, Zhang XJ, et al. Anabolic Effects of Insulin-Like Growth Factor in Combination with InsulinLike Growth Factor Binding Protein-3 in Severely Burned Adults. J Trauma 1999;47:904-10.

79. Hart DW, Wolf SE, Ramzy PI, et al. Anabolic Effects of Oxandrolone After Severe Burn. Ann Surg 2001;233:556-64.

80. Ferrando AA, Sheffield-Moore M, Wolf SE, et al. Testosterone administration in severe burns ameliorates muscle catabolism. Crit Care Med 2001;29:1936-42.

81. Hart DW, Wolf SE, Chinkes DL, et al. $\beta$-blockade and growth hormone after burn. Ann Surg 2002;236:450-6.

82. Orellana RA, Jeyapalan A, Escobar J, et al. Amino acids augment muscle protein synthesis in neonatal pigs during acute endotoxemia by stimulating mTOR-dependent translation initiation. Am J Physiol Endocrinol Metab 2007;293:E1416-25.

83. Orellana RA, Suryawan A, Wilson FA, et al. Development aggravates the severity of skeletal muscle catabolism induced by endotoxemia in neonatal pigs. Am J Physiol Regul Integr Comp Physiol 2012;302:R682-90.

84. Zamir O, Hasselgren PO, Frederick JA, et al. Is the metabolic response to sepsis in skeletal muscle different in infants and adults? An experimental study in rats. J Pediatr Surg 1992;27:1399-403.

85. Lang CH, Frost RA. Differential effect of sepsis on ability of leucine and IGF-I to stimulate muscle translation initiation. Am J Physiol Endocrinol Metab 2004;287:E721-30. 
86. Frost RA, Nystrom GJ, Jefferson LS, et al. Hormone, cytokine, and nutritional regulation of sepsis-induced increases in atrogin-1 and MuRF1 in skeletal muscle. Am J Physiol Endocrinol Metab 2007;292:E501-12.

87. Garibotto G, Russo R, Sofia A, et al. Skeletal muscle protein synthesis and degradation in patients with chronic renal failure. Kidney Int 1994;45:1432-9.

88. May RC, Kelly RA, Mitch WE. Metabolic acidosis stimulates protein degradation in rat muscle by a glucocorticoid-dependent mechanism. J Clin Invest 1986;77:614-21.

89. Mitch WE, Medina R, Grieber S, et al. Metabolic acidosis stimulates muscle protein degradation by activating the adenosine triphosphate-dependent pathway involving ubiquitin and proteasomes. J Clin Invest 1994;93:2127.

90. Odedra BR, Bates PC, Millward DJ. Time course of the effect of catabolic doses of corticosterone on protein turnover in rat skeletal muscle and liver. Biochem J 1983;214:617-27.

91. Moran A, Jacobs DR Jr, Steinberger J, et al. Association between the insulin resistance of puberty and the insulinlike growth factor-I/growth hormone axis. J Clin Endocrinol Metab 2002;87:4817-20.

92. Guercio G, Rivarola MA, Chaler E, et al. Relationship between the Growth Hormone/Insulin-Like Growth Factor-I Axis, Insulin Sensitivity, and Adrenal Androgens in Normal Prepubertal and Pubertal Girls. J Clin Endocrinol Metab 2003;88:1389-93.

93. Hartman ML, Veldhuis JD, Thorner MO. Normal Control of Growth Hormone Secretion. Horm Res 1993;40:37-47.

94. Baker J, Liu JP, Robertson EJ, et al. Role of insulin-like growth factors in embryonic and postnatal growth. Cell 1993;75:73-82.

95. Leger J, Carel C, Legrand I, et al. Magnetic resonance imaging evaluation of adipose tissue and muscle tissue mass in children with growth hormone $(\mathrm{GH})$ deficiency, Turner's syndrome, and intrauterine growth retardation during the first year of treatment with GH. J Clin Endocrinol Metab 1994;78:904-9.

96. Hayes VY, Urban RJ, Jiang J, et al. Recombinant Human Growth Hormone and Recombinant Human InsulinLike Growth Factor I Diminish the Catabolic Effects of Hypogonadism in Man: Metabolic and Molecular Effects 1. J Clin Endocrinol Metab 2001;86:2211-9.

97. Velloso CP. Regulation of muscle mass by growth hormone and IGF-I. Br J Pharmacol 2008;154:557-68.

98. Fang CH, Li BG, Wang JJ, et al. Insulin-Like Growth
Factor 1 Stimulates Protein Synthesis and Inhibits Protein Breakdown in Muscle From Burned Rats. JPEN J Parenter Enteral Nutr 1997;21:245-51.

99. Sotiropoulos A, Ohanna M, Kedzia C, et al. Growth hormone promotes skeletal muscle cell fusion independent of insulin-like growth factor 1 up-regulation. Proc Natl Acad Sci U S A 2006;103:7315-20.

100. Urban RJ. Growth Hormone and Testosterone: Anabolic Effects on Muscle. Horm Res Paediatr 2011;76:81-3.

101. Venken K, Movérare-Skrtic S, Kopchick JJ, et al. Impact of Androgens, Growth Hormone, and IGF-I on Bone and Muscle in Male Mice During Puberty. J Bone Miner Res 2007;22:72-82.

102. Mauras N, Rogol AD, Haymond MW, et al. Sex Steroids, Growth Hormone, Insulin-Like Growth Factor-1: Neuroendocrine and Metabolic Regulation in Puberty. Horm Res 1996;45:74-80.

103. Aynsley-Green A, Zachmann M, Prader A. Interrelation of the therapeutic effects of growth hormone and testosterone on growth in hypopituitarism. J Pediatr 1976;89:992-9.

104. Rosenfeld RG, Northcraft GB, Hintz RL. A Prospective, Randomized Study of Testosterone Treatment of Constitutional Delay of Growth and Development in Male Adolescents. Pediatrics 1982;69:681-7.

105.Sinha-Hikim I, Roth SM, Lee MI, et al. Testosteroneinduced muscle hypertrophy is associated with an increase in satellite cell number in healthy, young men. Am J Physiol Endocrinol Metab 2003;285:E197-205.

106. Toth MJ, Poehlman ET, Matthews DE, et al. Effects of estradiol and progesterone on body composition, protein synthesis, and lipoprotein lipase in rats. Am J Physiol Endocrinol Metab 2001;280:E496-501.

107. Rogol AD, Roemmich JN, Clark PA. Growth at puberty. J Adolesc Health 2002;31:192-200.

108. Taaffe DR, Jin IH, Vu TH, et al. Lack of effect of recombinant human growth hormone $(\mathrm{GH})$ on muscle morphology and GH-insulin-like growth factor expression in resistance-trained elderly men. J Clin Endocrinol Metab 1996;81:421-5.

109. Yarasheski KE, Campbell JA, Smith K, et al. Effect of growth hormone and resistance exercise on muscle growth in young men. Am J Physiol 1992;262:E261-7.

110.Drummond MJ, Bell JA, Fujita S, et al. Amino acids are necessary for the insulin-induced activation of mTOR/ S6K1 signaling and protein synthesis in healthy and insulin resistant human skeletal muscle. Clin Nutr 2008;27:447-56.

111. Garlick PJ, Grant I. Amino acid infusion increases 
the sensitivity of muscle protein synthesis in vivo to insulin. Effect of branched-chain amino acids. Biochem J 1988;254:579-84.

112.Wilson FA, Suryawan A, Gazzaneo MC, et al. Stimulation of muscle protein synthesis by prolonged parenteral infusion of leucine is dependent on amino acid availability in neonatal pigs. J Nutr 2010;140:264-70.

113. McNelly AS, Bear DE, Connolly BA, et al. Effect of Intermittent or Continuous Feed on Muscle Wasting in Critical Illness: A Phase 2 Clinical Trial. Chest 2020;158:183-94.

114. Kindler JM, Pollock NK, Laing EM, et al. Insulin Resistance Negatively Influences the Muscle-Dependent IGF-1-Bone Mass Relationship in Premenarcheal Girls. J Clin Endocrinol Metab 2016;101:199-205.

115. Thivierge MC, Bush JA, Suryawan A, et al. Whole-body and hindlimb protein breakdown are differentially altered by feeding in neonatal piglets. J Nutr 2005;135:1430-7.

116. Kawano F, Takeno Y, Nakai N, et al. Essential role of satellite cells in the growth of rat soleus muscle fibers. Am J Physiol Cell Physiol 2008;295:C458-67.

117. Vingren JL, Kraemer WJ, Ratamess NA, et al. Testosterone physiology in resistance exercise and training: the up-stream regulatory elements. Sports Med 2010;40:1037-53.

118. Ramsay JA, Blimkie CJ, Smith K, et al. Strength training effects in prepubescent boys. Med Sci Sports Exerc 1990;22:605-14.

119. Moore DR, Volterman KA, Obeid J, et al. Postexercise protein ingestion increases whole body net protein balance in healthy children. J Appl Physiol (1985) 2014;117:1493-501.

120. Finnerty CC, Jeschke MG, Herndon DN, et al. Temporal Cytokine Profiles in Severely Burned Patients: A Comparison of Adults and Children. Molecular Medicine 2008;14:553-60.

121. Wray CJ, Mammen JM, Hershko DD, et al. Sepsis upregulates the gene expression of multiple ubiquitin ligases in skeletal muscle. Int J Biochem Cell Biol 2003;35:698-705.

122. Hart DW, Wolf SE, Chinkes DL, et al. Determinants of skeletal muscle catabolism after severe burn. Annals of Surgery 2000;232:455-65.

123.Przkora R, Herndon DN, Suman OE. The Effects of Oxandrolone and Exercise on Muscle Mass and Function in Children With Severe Burns. Pediatrics 2007;119:e109-16.

124. Biolo G, Fleming RYD, Maggi SP, et al. Inverse regulation of protein turnover and amino acid transport in skeletal muscle of hypercatabolic patients. J Clin Endocrinol Metab 2002;87:3378-84.

125.Alexander JW, MacMillan BG, Stinnett JD, et al. Beneficial effects of aggressive protein feeding in severely burned children. Ann Surg 1980;192:505-17.

126.Suman OE, Thomas SJ, Wilkins JP, et al. Effect of exogenous growth hormone and exercise on lean mass and muscle function in children with burns. J Appl Physiol (1985) 2003;94:2273-81.

127.Przkora R, Herndon DN, Suman OE, et al. Beneficial effects of extended growth hormone treatment after hospital discharge in pediatric burn patients. Ann Surg 2006;243:796-801.

128. Murphy KD, Thomas S, Mlcak RP, et al. Effects of longterm oxandrolone administration in severely burned children. Surgery 2004;136:219-24.

129. Porro LJ, Herndon DN, Rodriguez NA, et al. Five-year outcomes after oxandrolone administration in severely burned children: a randomized clinical trial of safety and efficacy. J Am Coll Surg 2012;214:489-502; discussion 502-4.

130. Gardelis JG, Hatzis TD, Stamogiannou LN, et al. Activity of the growth hormone/insulin-like growth factor-I axis in critically ill children. J Pediatr Endocrinol Metab 2005;18:363-72.

131. de Groof F, Joosten KF, Janssen JA, et al. Acute Stress Response in Children with Meningococcal Sepsis: Important Differences in the Growth Hormone/InsulinLike Growth Factor I Axis between Nonsurvivors and Survivors. J Clin Endocrinol Metab 2002;87:3118-24.

132. Orellana RA, O'Connor PM, Nguyen HV, et al. Endotoxemia reduces skeletal muscle protein synthesis in neonates. Am J Physiol Endocrinol Metab 2002;283:E909-16.

133. Menconi M. Role of glucocorticoids in the molecular regulation of muscle wasting. Crit Care Med 2007;35:S602-8.

134. Sandri M, Sandri C, Gilbert A, et al. Foxo transcription factors induce the atrophy-related ubiquitin ligase atrogin-1 and cause skeletal muscle atrophy. Cell 2004;117:399-412.

135. Wang H, Kubica N, Ellisen LW, et al. Dexamethasone Represses Signaling through the Mammalian Target of Rapamycin in Muscle Cells by Enhancing Expression of REDD1. J Biol Chem 2006;281:39128-34.

136. Gayan-Ramirez G, Vanderhoydonc F, Verhoeven G, et al. Acute treatment with corticosteroids decreases IGF-1 and IGF-2 expression in the rat diaphragm and gastrocnemius. 
Am J Respir Crit Care Med 1999;159:283-9.

137. Braun TP, Szumowski M, Levasseur PR, et al. Muscle atrophy in response to cytotoxic chemotherapy is dependent on intact glucocorticoid signaling in skeletal muscle. PLoS One 2014;9:e106489.

138. Steiner SJ, Noe JD, Denne SC. Corticosteroids Increase Protein Breakdown and Loss in Newly Diagnosed Pediatric Crohn Disease. Pediatr Res 2011;70:484-8.

139. Covar RA, Leung DYM, McCormick D, et al. Risk factors associated with glucocorticoid-induced adverse effects in children with severe asthma. J Allergy Clin Immunol 2000;106:651-9.

140. Boirie Y, Broyer M, Gagnadoux MF, et al. Alterations of protein metabolism by metabolic acidosis in children with chronic renal failure. Kidney Int 2000;58:236-41.

141. Tsampalieros A, Kalkwarf HJ, Wetzsteon RJ, et al. Changes in bone structure and the muscle-bone unit in children with chronic kidney disease. Kidney Int 2013;83:495-502.

142. Foster BJ, Kalkwarf HJ, Shults J, et al. Association of Chronic Kidney Disease with Muscle Deficits in Children. Journal of the American Society of Nephrology 2011;22:377-86.

143. Faustino EV, Apkon M. Persistent hyperglycemia in critically ill children. J Pediatr 2005;146:30-4.

144. Hulst J, Joosten K, Zimmermann L, et al. Malnutrition in critically ill children: from admission to 6 months after discharge. Clin Nutr 2004;23:223-32.

145. Giuliano JS Jr, Faustino EV, Li S, et al. Corticosteroid therapy in critically ill pediatric asthmatic patients. Pediatr Crit Care Med 2013;14:467-70.

146. Verdijk LB, Snijders T, Drost M, et al. Satellite cells in human skeletal muscle; from birth to old age. Age (Dordrecht, Netherlands) 2014;36:545-7.

147. Verbruggen SC, Schierbeek H, Coss-Bu J, et al. Albumin synthesis rates in post-surgical infants and septic adolescents; influence of amino acids, energy, and insulin. Clinical Nutrition 2011;30:469-77.

148. Verbruggen SCAT, Coss-Bu J, Wu M, et al. Current

Cite this article as: Ong C, Lee JH, Leow MKS, Puthucheary ZA. A narrative review of skeletal muscle atrophy in critically ill children: pathogenesis and chronic sequelae. Transl Pediatr 2021;10(10):2763-2777. doi: 10.21037/tp-20-298 recommended parenteral protein intakes do not support protein synthesis in critically ill septic, insulin-resistant adolescents with tight glucose control. Crit Care Med 2011;39:2518-25.

149.Lee D, Wetzsteon R, Zemel B, et al. Muscle strength and the functional muscle-bone unit in children and adolescents with chronic disease. J Bone Miner Res 2013;28.

150.Pollack MM, Holubkov R, Funai T, et al. Pediatric intensive care outcomes: development of new morbidities during pediatric critical care*. Pediatr Crit Care Med 2014;15:821-7.

151. Ong C, Lee JH, Senna S, et al. Body Composition and Acquired Functional Impairment in Survivors of Pediatric Critical Illness. Crit Care Med 2019;47:e445-53.

152.Johnson RW, Ng KWP, Dietz AR, et al. Muscle atrophy in mechanically-ventilated critically ill children. PLoS One 2018;13:e0207720.

153.Zamberlan P, Feferbaum R Associate Professor of Pediatrics, Doria Filho U, et al. Bioelectrical Impedance Phase Angle and Morbidity and Mortality in Critically Ill Children. Nutr Clin Pract 2019;34:163-71. Erratum in: Nutr Clin Pract 2020;35:366.

154. Valla FV, Young DK, Rabilloud M, et al. Thigh Ultrasound Monitoring Identifies Decreases in Quadriceps Femoris Thickness as a Frequent Observation in Critically Ill Children*. Pediatr Crit Care Med 2017;18:e339-47.

155. Cala MP, Agulló-Ortuño MT, Prieto-García E, et al. Multiplatform plasma fingerprinting in cancer cachexia: a pilot observational and translational study. J Cachexia Sarcopenia Muscle 2018;9:348-57.

156.Yang QJ, Zhao JR, Hao J, et al. Serum and urine metabolomics study reveals a distinct diagnostic model for cancer cachexia. J Cachexia Sarcopenia Muscle 2018;9:71-85.

157. Rooyackers OE, Nair KS. Hormonal regulation of human muscle protein metabolism. Annu Rev Nutr 1997; 17:457-85. 